\title{
Concentrations of Polycyclic Aromatic Hydrocarbons from Selected Dumpsites Within Port Harcourt Metropolis, Rivers State, Niger Delta, Nigeria
}

\author{
Ekpete $\mathrm{OA}^{1}$, Edori $\mathrm{OS}^{1 *}$ and Iyama $\mathrm{WA}^{2}$ \\ ${ }^{1}$ Department of Chemistry, Ignatius Ajuru University of Education, Nigeria \\ ${ }^{2}$ School of Basic Studies, Rivers State College of Health Science and Technology, Nigeria
}

Submission: September 05, 2019; Published: September 23, 2019

*Corresponding author: Edori OS, Department of Chemistry, Ignatius Ajuru University of Education, Port Harcourt, P.M.B.5047, Nigeria

Abstract

Soil samples were collected from three dumpsites (Chakiricha, Psychiatric and Rumuokwuta) within Port Harcourt metropolis and examined for the concentrations of polycyclic aromatic hydrocarbons (PAHs). The study showed that there was heavy presence of PAHs in the dumpsites. The total concentrations of PAHs in the dumpsites were in the order; Rumuokwuta > Chakiricha > Psychiatric with values of 60.958, 30.036 and $21.987 \mathrm{mg} / \mathrm{Kg}$ respectively. There was the predominance of 2-3 membered ring PAHs in Rumuokwuta and Psychiatric dumpsites while at the Chakiricha dumpsite, it was the 4 membered rings that dominated. The diagnostic and source identification of PAHs in the dumpsites showed multiple sources but dominated by pyrogenic sources. The difference between carcinogenic and non-carcinogenic PAHs in the dumpsites shows almost equally competing concentrations of the two classes thus therefore inferring the closeness of human to risks of cancer within the area.

Keywords: Polycyclic aromatic hydrocarbons; Dumpsites; Environment; Pollution; Soil

\section{Introduction}

Advancement in technology, economic growth, population increase and human need for food, clothes, vehicles, home appliances and enhanced health amenities has led to increased agricultural, domestic and industrial activities, which end in the generation and release of wastes in different forms into the environment [1]. Environmental contamination and pollution are dangerous to man and his environment. The need to curb the effect of pollution in the environment has necessitated the development of standard permissible limits for different chemical substance in the environment by both national and international agencies [2]. The essence is to regulate the discharge of pollutants into the environment with acceptable limits to avoid negative health implications and consequences [3].

Despite these steps, the issue of contamination of soils, land, water and air has continued unabated. Scientists and environmentalist and technologists are faced with the challenges of overcoming the harmful effects of contamination of the soil. Inconsiderate dumping and maladministration of waste and other by-products from homes and industries create the main source of contaminations in the environment [4]. The soil is known as the repository for pollutants, whether polycyclic aromatic hydrocarbons, heavy metals or other pollutants. When pollutants such as polycyclic aromatic hydrocarbons are constantly discharged into the soil, they subsequently accumulate to level that can constitute risk to the environment [5].

The accumulation of these compounds in the soil can lead to contamination of food chain, since plants derive their nutrients from the soil and are eaten by man and animals. Beside the intake by plants within the immediate vicinity, there is the issue of redistribution by leaching and runoffs and transformation by microbes. The presence of polycyclic aromatic hydrocarbons in the environment is presently on focus, due to the fact that they are considered as responsible or as precursors of some diseased conditions such as carcinogenicity, mutagenicity, teratogenicity and other toxic effects [6].

Polycyclic aromatic hydrocarbons (PAHs) are possible atmospheric toxins which comprises of fused aromatic rings without considering those that have substituents [7]. They are distinctive pollutants in the environment and are produced constantly from incomplete combustion of waste, petroleum products, coal, 
organic materials and tobacco. Other sources of environmental PAHs are volcanic eruptions, forest fires, coal burning, asphalt production and fumes from car exhaust [8].

In Port Harcourt, Rivers State, Nigeria, there are government approved dumpsites. In these dumpsites, wastes are expected to be evacuated on daily basis, but sometimes, there are delays or occasional incineration by the people. This study was therefore undertaken to study the concentrations of polycyclic aromatic hydrocarbons in selected government approved dumpsites within Port Harcourt metropolitan city.

\section{Materials and Methods}

\section{Sample collection}

Surface soil samples from three dumpsite locations within the Rumuigbo-Rumuokwuta axis were collected with soil auger after removing the covering wastes. The soil samples were collected randomly from five points within the waste dumpsites and mixed together to form representative samples. The chosen dumpsites were Chakiricha dumpsite (near Monier Construction Company, MCC) in Rumuigbo, Rumuomio dumpsites along psychiatric road Rumuigbo and Rumuokwuta dumpsite near MTN office. The samples were collected at the depth of $0-10 \mathrm{~cm}$ and placed in glass container, which were immediately covered. The samples were immediately taken to the laboratory for analysis.

\section{Sample preparation and extraction of PAHs}

Proceeding to the extraction, soil samples were homogenized to powder and sieved with a $0.2 \mathrm{~mm}$ mesh. Thereafter, $2.5 \mathrm{~g}$ of the sieved sample was introduced into a soxhlet extractor and extraction was done with $10 \mathrm{ml}$ of methanol and $25 \mathrm{ml}$ of dichloromethane for 24 hours at $800 \mathrm{C}$ with constant refluxing. The extract was eluted into a $250 \mathrm{ml}$ and purified using dichloromethane solvent. Then a rotary evaporator was used to concentrate the extract to $5 \mathrm{ml}$. Further purification was carried out in a $50 \mathrm{ml}$ flat bottom flask with addition of $15 \mathrm{ml}$ pentane, which was volatilized with rotary extractor to $2 \mathrm{ml}$. The pentane extract was further concentrated by evaporation to $0.5 \mathrm{ml}$ using a constant flow of uncontaminated nitrogen gas. This was permitted to pass over slurry packed column of activated silica gel for 8 hours at a controlled temperature of $200 \mathrm{oC}$. All other hydrocarbon constituents were separated from PAHs using a pentane solvent first

Table 1: Concentrations $(\mathrm{mg} / \mathrm{Kg}$ ) of polycyclic aromatic hydrocarbons (PAHs) in soil samples from the selected waste dumps.

\begin{tabular}{|c|c|c|c|}
\hline \multirow{2}{*}{ PAHs (mg/Kg) } & \multicolumn{3}{|c|}{ Dumpsites } \\
\hline & Chakiricha & Psychiatric & Rumuokwuta \\
\hline Napthalene & $\mathrm{Nd}$ & $\mathrm{Nd}$ & $9.575 \pm 2.013$ \\
\hline Acenapthylene & $\mathrm{Nd}$ & $\mathrm{Nd}$ & $8.713 \pm 1.465$ \\
\hline Acenaphthene & $\mathrm{Nd}$ & $3.248 \pm 1.261$ & $5.748 \pm 2.134$ \\
\hline Fluorene & $\mathrm{Nd}$ & $5.151 \pm 1.332$ & $4.118 \pm 1.664$ \\
\hline Phenanthrene & $4.531 \pm 1.352$ & $3.450 \pm 1.021$ & $1.814 \pm 0.125$ \\
\hline Anthracene & $0.146 \pm 0.364$ & $1.390 \pm 0.861$ & $6.434 \pm 2.519$ \\
\hline
\end{tabular}


International Journal of Environmental Sciences \& Natural Resources

\begin{tabular}{|c|c|c|c|}
\hline Fluoranthene & $3.888 \pm 0.896$ & $0.314 \pm 0.02$ & $1.518 \pm 0.376$ \\
\hline Pyrene & $3.132 \pm 1.354$ & Nd & $0.639 \pm 0.214$ \\
\hline Benzo (a) Anthracane & $2.716 \pm 0.297$ & $0.369 \pm 0.041$ & $3.639 \pm 1.361$ \\
\hline Chrysene & $3.380 \pm 1.102$ & $0.769 \pm 0.121$ & $5.693 \pm 1.932$ \\
\hline Benzo (b) fluoranthene & $1.431 \pm 0.502$ & $2.773 \pm 1.126$ & $5.693 \pm 2.256$ \\
\hline Benzo (k) Fluoranthene & $1.046 \pm 0.336$ & $1.015 \pm 0.138$ & $\mathrm{Nd}$ \\
\hline Benzo (a) pyrene & $1.046 \pm 0.618$ & $1.355 \pm 0.046$ & $0.072 \pm 0.001$ \\
\hline Benzo (g,h,i) Pyrene & $3.630 \pm 2.011$ & $1.138 \pm 1.002$ & $1.040 \pm 0.011$ \\
\hline Dibenzo (a,h)Anthracene & $2.363 \pm 0.659$ & $0.222 \pm 0.005$ & $1.248 \pm 0.382$ \\
\hline Indeno (1,2,3-cd) pyrene & $2.727 \pm 1.001$ & $0.793 \pm 0.167$ & $5.014 \pm 2.561$ \\
\hline
\end{tabular}

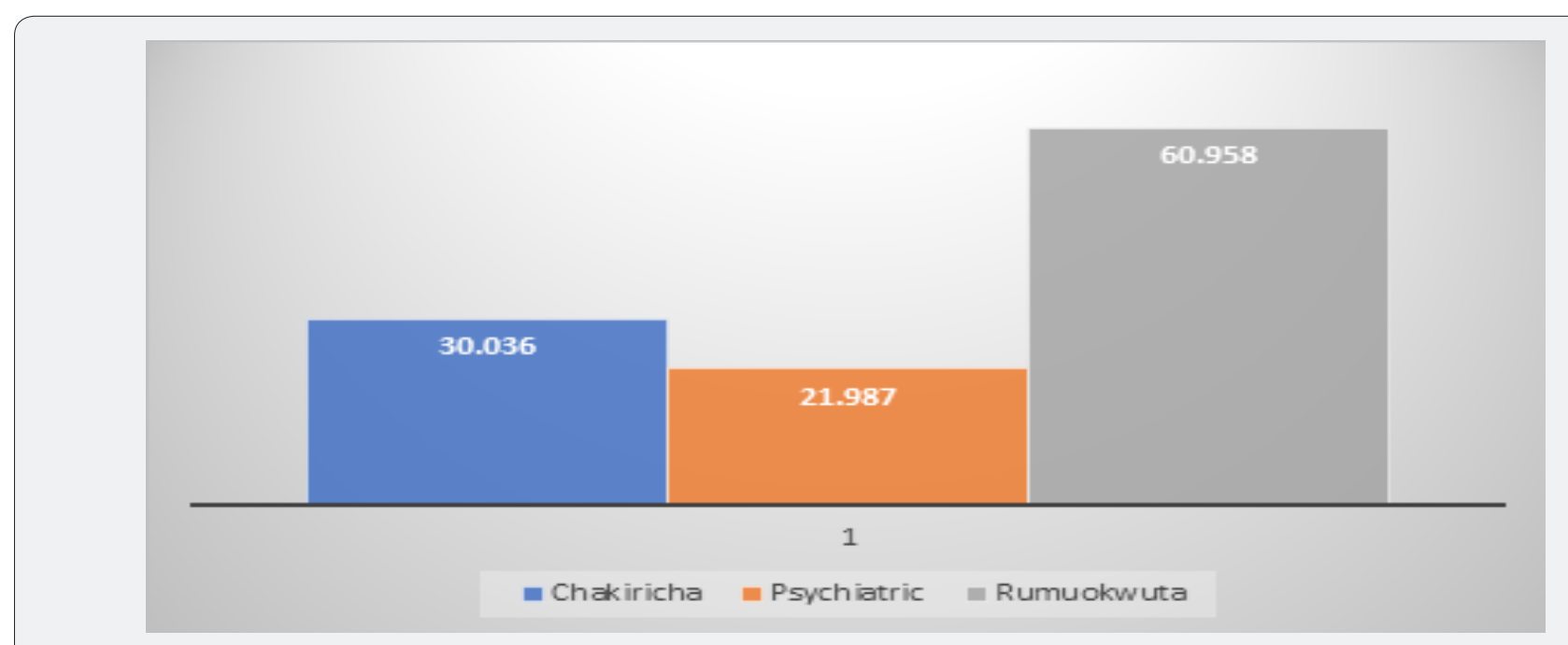

Figure 1: Total concentrations of polycyclic aromatic hydrocarbons in the dumpsites.

The total content of PAHs in this dumpsite was $60.958 \mathrm{mg} /$ Kg.

The Rumuokwuta dumpsite had the highest concentrations of PAHs, which was followed by the Chakiricha dumpsite and then the psychiatric dumpsite. The presence of high levels of PAHs in environment has negative health effects on humans within the area [9]. These could have resulted from incomplete combustion of waste materials usually dumped at these points [10]. The presence of PAHs in soil has the potentials to pollute both ground water and surface water by leaching through the soil profile and through runoffs to nearby water body $[11,12]$. The implications of PAHs present in water to man and other animals (fishes inclusive) cannot be overlooked. This is due to the fact that their presence in water can either have direct effect on man or indirect effect through food chain and loss of aquatic life through toxicity [13].

The total values of PAHs observed in the present work fall within the range of values observed in Igbore and Saje dumpsites in Abeokuta metropolis, South West, Nigeria where total values of PAHs were observed to vary between 11.0 and $41.6 \mathrm{mg} /$ $\mathrm{Kg}$ [14]. But either higher or within the range of values observed in open-pit coal mine, China, where the observed range fall within $0.06-36.90 \mathrm{mg} / \mathrm{Kg}$ within a depth range of $0-100 \mathrm{~cm} \mathrm{[15]} \mathrm{and}$ lower than the total values of PAHs observed in soil from electronic waste dumpsites in Lagos and Ibadan, Nigeria, where the values were in the region of $1756-2224 \mu \mathrm{g} / \mathrm{Kg}$ in a $0-15 \mathrm{~cm}$ depth of top soil [16]. According to Kaszubkiewicz et al. [17], the Dutch stipulated values for intervention for PAHs contamination in any soil is $40 \mathrm{mg} / \mathrm{Kg}$. However, the values obtained in the dumpsite from the present work showed that Rumuokwuta dumpsite content of PAHs was higher than the intervention value, Chakiricha was close to the value and therefore at alarming stage, while Psychiatric dumpsite is not yet at the alarming stage.

The observed values of PAHs in the dumpsite seem to be associated with population size, which in part is a determining factor in output of waste. The human cluster population and dumpsite size seem to be more at Rumuokwuta, then Chakiricha and finally Psychiatric area, so also was the total PAHs concentrations in the dumpsites. Despite the fact that some of the values were lower than the above guidelines, communities within the area stand the risk of being affected by the PAHs, thus posing great health challenges and risk of being transported to nearby water sources [14]. 


\section{Diagnosis and source apportionment of PAHs from the dumpsites}

The sources of the identified PAHs in the examined dumpsites are shown in Table 2. The determination of the PAHs sources using the diagnostic ratios showed that the ratio of LMW/ HMW PAHs gave values of $0.184,1.513$ and 1.482 for Chakiricha, Psychiatric and Rumuokwuta dumpsites respectively. These values indicated that PAHs in Chakiricha dumpsites was pyrogenic, while at Psychiatric and Rumuokwuta was petrogenic. The source analysis for 2-3 rings PAHs (An/An+Phe) in the dumpsites showed values of $0.031,0.287$ and 0.780 for Chakiricha, Psychiatric and Rumuokwuta dumpsites. The obtained values indicated that Chakiricha dumpsite was of petrogenic origin, Table 2: Diagnostic ratios and Source apportionment of PAHs in the Dumpsites.

\begin{tabular}{|c|c|c|c|c|c|}
\hline Stations & LMW/HMW & An/(An+Phe) & Fl/(Fl+Pyr) & BaA/(BaA+Chr) & IP/ (IP+ BgP) \\
\hline Chakiricha & 0.184 & 0.031 & 0.554 & 0.446 & 0.536 \\
\hline Psychiatric & 1.513 & 0.287 & 1 & 0.324 & 0.781 \\
\hline Rumuokwuta & 1.482 & 0.78 & 0.704 & 0.39 & 0.801 \\
\hline
\end{tabular}

The observed multiple sources of PAHs in the different stations corroborates the findings of Edori and Iyama [12] at effluents discharge points into the New Calabar River, those of Xiaoyang et al. [15] in the soil profiles from the industrial district of large open-pit coal mine, China, those of Olufunmilayo et al. [14] in selected dumpsites in Abeokuta Metropolis, South West, Nigeria and those of Ilechukwu et al. [18] from different asphalt hot-mix plant stations within Port Harcourt City, Rivers State, South-South, Nigeria.

Polycyclic hydrocarbons of pyrogenic origin results from high-temperature incineration produced from oxygen depleted burning or combustion of organic based materials such as fossil fuel, exhaust fumes, manufacturing associated with heat production and waste furnaces [19]. The class of PAHs produced from pyrogenic sources is mostly compounds which contain unsubstituted aromatic rings and they form the basic PAHs configurations [20]. Despite the fact that in the present work, combustion-based PAHs (pyrogenic) predominated over the non-combustion-based PAHs (petrogenic) yet petrogenic PAHs may have been contributed in each of the selected dumpsites

Table 3: Diagnostic ratios and Source apportionment of PAHs in the Dumpsites.

\begin{tabular}{|c|c|c|c|}
\hline \multirow{2}{*}{ PAHs Ring Size } & \multicolumn{3}{|c|}{ Dumpsites } \\
\cline { 2 - 4 } & Chakiricha & Psychiatric & Rumuokwuta \\
\hline $2-3$ & 4.677 & 13.239 & 11.489 \\
\hline 4 & 13.116 & 1.452 & 6.805 \\
\hline 5 & 7.153 & 6.281 & 6.262 \\
\hline
\end{tabular}

The concentrations of the carcinogenic and non-carcinogenic PAHs in the dumpsites showed the values of carcinogenic PAHs was $14.702,7.296$ and $21.359 \mathrm{mg} / \mathrm{Kg}$ for Chakiricha, Psychiatric and Rumuokwuta stations respectively, while those while Psychiatric and Rumuokwuta dumpsites were of pyrogenic origin. The source diagnosis for the four rings PAHs (Fl/Fl+Py) in the three dumpsites were Chakiricha (0.554), Psychiatric (1.000) and Rumuokwuta (0.704). All the values obtained for the dumpsites indicated pyrogenic sources of the compounds. The diagnostic evaluation of the five-membered rings PAHs (BaA/ $\mathrm{BaA}+\mathrm{Chr}$ ) gave values of 0.446 .0 .324 and 0.390 for Chakiricha, Psychiatric and Rumuokwuta dumpsites respectively. These values showed that all the dumpsites were affected by petrogenic PAHs. The six membered-ring (IP/IP+BgP) analysis for source identification gave values of $0.536,0.781$ and 0.801 in Chakiricha, Psychiatric and Rumuokwuta dumpsites respectively.

through other road transport activities, occasional spills and other natural factors. This observation corroborates the observation of Wang et al. [21].

\section{Ring size analysis of PAHs in the dumpsite}

The concentrations of the different ring categories in the sampled dumpsites are given in Table 3. The content of the different PAHs classes showed that 2-3 membered rings were the lowest with a value of $4.677 \mathrm{mg} / \mathrm{Kg}$, which was followed by the values of the 6 membered rings which was $5.090 \mathrm{mg} / \mathrm{Kg}$, then 5 membered rings, which was $7.153 \mathrm{mg} / \mathrm{Kg}$ and the highest were the 4 membered rings which was $13.116 \mathrm{mg} / \mathrm{Kg}$. In the Psychiatric dumpsite, the highest concentration of the different PAHs category was observed in the 2-3 membered rings, with a value of $13.239 \mathrm{mg} / \mathrm{Kg}$. The values for the other membered rings were $6.281,1.452$ and $1.015 \mathrm{mg} / \mathrm{Kg}$ for 5,4 and 6 membered rings respectively. In the Rumuokwuta dumpsite, the observed values indicated that the low molecular weight PAHs (2-3) was the highest with a value of $36.402 \mathrm{mg} / \mathrm{Kg}$, while the values of the other ring sizes were $11.489,6.805$ and $6.262 \mathrm{mg} / \mathrm{Kg}$ for 4,5 and 6 membered rings respectively. of the non-carcinogenic PAHs in the dumpsites were 15.334, 14.691 and $39.602 \mathrm{mg} / \mathrm{Kg}$ for the respective stations.

The most important characteristics of the fate and toxicity of polycyclic aromatic compound in any contaminated soils is 
dependent on the extent of solubility in fats and partitioning between organic and other particulates surfaces [3]. Ordinarily, it is a well-known fact that the higher molecular weight PAHs display considerable propensity than the lower molecular weight PAHs and remain sorbed to soils or sediment rather than remain in the water or air and also have the greater capacity to bio-accumulate in organisms. In the present work, there is a relative comparison between the LMW PAHs and HMW PAHs. The very high values of the LMW PAHs may have resulted from the release of unburnt petroleum products (petrol, diesel and, grease and other vehicular oils) from vehicles released during traffic congestion [3]. This condition (traffic congestion) is a common site at the Rumuokwuta dumpsite, which is the same with the Psychiatric dumpsite area, but lesser at the Chakiricha dumpsite area. Therefore, the very high level of the lower molecular weight PAHs in the Rumuokwuta and Psychiatric dumpsite may be associated with traffic issues.
Low molecular weight PAHs, that is the 2-3 membered rings easily undergo transformation through bacterial and fungal degradation effects, while high molecular weight PAHs (4-6 membered rings) have more resistance to environmental conditions and so are not easily degraded to other products either by chemical or microbial activities [22].

The nature and ratio of the occurrence of both carcinogenic and non-carcinogenic PAHs in the dumpsites were relatively close to each other. This is an indication that these dumpsites can pose or constitute risk to the environment. Notably so, these dumpsites are positioned in the heartbeat of the various settlements. This implies that during overflows resulting from rainwater, which is a common occurrence within the area, can lead to transport or transfer of these toxic compounds into wells and lands (soils) within the spread area (Table 4).

Table 4: Total concentrations (mg/Kg) of carcinogenic and non-carcinogenic PAHs in the dumpsites.

\begin{tabular}{|c|c|c|c|}
\hline \multirow{2}{*}{ PAHs Type } & \multicolumn{2}{|c|}{ Dumpsites } \\
\cline { 2 - 4 } & Chakiricha & \multicolumn{2}{|c|}{ Psychiatric } \\
\hline Carcinogeni PAHs & 14.702 & 7.296 & 14.691 \\
\hline Non-carcinogenic PAHs & 15.334 & 39.602 & \\
\hline
\end{tabular}

\section{Conclusion}

The study revealed that PAHs in the dumpsites were highly concentrated. Moreover, there was predominance of 2-3 membered rings in majority of the dumpsites, thus revealing intense human interferences or pyrogenic sources of PAHs than petrogenic sources. The diagnostic ratios of the different ring categories showed variable sources of PAHs in the dumpsite, although there was the dominance of pyrogenic sources over petrogenic sources. The ratio of carcinogenic to non-carcinogenic PAHs were relatively close, this portends health danger signals to the immediate human environment and also reveal the congestion nature of vehicular traffic. To effectively practice waste management and control in urban settlement, there is the need to protect nearby environments from the spread or transport of toxic substances from the immediate source of production. The very high values of PAHs in the dumpsites, therefore, call for immediate attention of the government so as to arrest or forestall any negative health effect in the near future. The authorities responsible for evacuating refuse should not allow the dumps to remain for a long time at the dumpsite and not also burn them as is the practice in most cases when it is the dry season. From the outcome of this study, it is recommended that these dumpsites be stopped immediately and be moved to places that are far from human environments and settlements.

\section{References}

1. Shitandayi A, Orata F, Lisouza F (2019) Assessment of environmental sources, levels and distribution of polycyclic aromatic hydrocarbons within Nzoia Catchment area in Kenya. Journal of Environmental Protection 10(6): 772-790.
2. United States Environmental Protection Agency (USEPA) (1993) Provisional guidance for the polycyclic aromatic hydrocarbons. EPA/600/R 93/089.

3. Canadian Council of Ministers of Environment, CCME (2008) Canadian Soil Quality Guidelines. Carcinogenic and other polycyclic aromatic hydrocarbons (PAHs) (Environmental and Human Health Effects), Scientific Supporting Document. pp. 1-229.

4. Carruthers J, Ulfarsson, G (2012) Urban sprawl and the cost of public services. Environment and Planning B. Planning and Design 30: 503522.

5. Edokpayi NJ, Odiyo JO, Popoola OE, Msagati TAM (2016) Determination and distribution of polycyclic aromatic hydrocarbons in rivers, sediments and wastewater effluents in Vhembe District, South Africa. Int J Environ Res Public Health 13(4): 387.

6. Oleszczuk P, Baran S, Baranwska E (2003) Degradation of soil environment in the post flooding area: Content of polycyclic aromatic hydrocarbons (PAHs) and Striasin herbicides. J Environ Sci Health B 38(6): 799-812.

7. Fetzer JC (2000) The chemistry and analysis of the large polycyclic aromatic hydrocarbon. Polycyclic aromatic compound 27(2): 143-162.

8. Ogunfowokan AO, Asubiojo OI, Fatoki OS (2003) Isolation and determination of polycyclic aromatic hydrocarbons in surface runoff and sediments. Water, Air and Soil Pollution 147(1-4): 245-261.

9. Adedosu TA, Adeniyi OK, Adedosu HO (2015) Distribution, Sources and Toxicity Potentials of Polycyclic Aromatic Hydrocarbons in Soil around the Vicinity of Balogun-birro Dumpsite of Oshogbo, Nigeria. Malaysian Journal of Analytical Sciences 19 (3): 636-648.

10. Korosi JB, Irvine G, Skierszkan EK, Doyle JR, Kimpe LE, et al. (2013) Localized enrichment of polycyclic aromatic hydrocarbons in soil, spruce needles, and lake sediments linked to in-situ bitumen extraction near Cold Lake, Alberta. Environ Pollut 182: 307-315. 
11. Al-Delaimy WK, Larsen WC, Pezzoli K (2014) Differences in health symptoms among residents living near illegal dumpsites in Los Laurels Canyin, Tijuanan, Mexico: A cross sectional survey. Int J Environ Res Public Health 11(9): 9532-9552.

12. Edori OS, Iyama WA (2019) Source Identification of Polycyclic aromatic hydrocarbons in water at point of effluent discharge into the New Calabar River, Port Harcourt, Rivers State, Nigeria. International Journal of Environment and Climate Change 9(6): 343-349.

13. Ifemeje JC, Udedi SC, Lukong CB, Okechukwu AU, Egbuna C (2014) Distribution of polycyclic aromatic hydrocarbons and heavy metals in soils from municipal solid waste landfill. British Journal of Applied Science and Technology 4(36): 5058-5071.

14. Olufunmilayo 00, Oludare HA, Rotimi AI (2015) Determination of polycyclic aromatic hydrocarbons (PAHs) on selected dumpsites in Abeokuta Metropolis, SW, Nigeria. Applied Environmental Research 37(3): 33-48.

15. Xiaoyang L, Zhongke B, Qinfei Y, Yingui C, Wei Z (2017) Polycyclic aromatic hydrocarbons in the soil profiles $(0-100 \mathrm{~cm})$ from the industrial district of a large open-pit coal mine, China. Royal Society of Chemistry Advances 7(45): 28029-28037.

16. Adeyi AA, Oyeleke P (2017) Heavy Metals and Polycyclic Aromatic Hydrocarbons in Soil from E-waste dumpsites in Lagos and Ibadan, Nigeria. J Health Pollut 7(15): 71- 84.

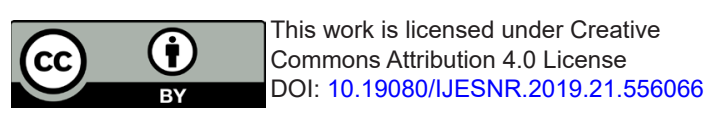

17. Kaszubkiewicz J, Kawałko D, Perlak Z (2010) Concentration of polycyclic aromatic hydrocarbons in surface horizons of soils in immediate neighbourhood of illegal waste dumps. Polish Journal of Environmental Studies 19(1): 73-82.

18. Ilechukwu I, Osuji LC, Onyema MO (2016) Source apportionment of polycyclic aromatic hydrocarbons (PAHs) in soils within hot mix asphalt (HMA) plant vicinities. Journal of Chemical Society of Nigeria 41(2): 10-16

19. Banger K, Toor GS, Chirenje T, Ma L (2010) Polycyclic aromatic hydrocarbons in urban soils of different land uses in Miami, Florida. Soil and Sediment Contamination 19(2): 231-243.

20.Wickliffe J, Overton E, Frickel S, Howard J, Wilson M, et al. (2014) Evaluation of polycyclic aromatic hydrocarbons using analytical methods, toxicology, and risk assessment research: seafood safety after a petroleum spill as an example. Environ Health Perspect 122(1): 6-9.

21. Wang X, Cheng H, Xu X, Zhuang G, Zhao C (2008) A wintertime study of polycyclic aromatic hydrocarbons in PM2.5 and PM2.5-10 in Beijing: Assessment of energy structure conversion. Journal of Hazardous Materials 157(1): 47-56.

22. Carl EC, John BS (2009) Bioremediation of polycyclic aromatic hydrocarbons by liqninolytic and non-ligninolytic fungi. London: Cambridge University press. 13687.

\section{Your next submission with Juniper Publishers will reach you the below assets}

- Quality Editorial service

- Swift Peer Review

- Reprints availability

- E-prints Service

- Manuscript Podcast for convenient understanding

- Global attainment for your research

- Manuscript accessibility in different formats ( Pdf, E-pub, Full Text, Audio)

- Unceasing customer service

Track the below URL for one-step submission https://juniperpublishers.com/online-submission.php 